\title{
PROBLEMS OF BONE - ORTHOPAEDIC IMPLANT INTERACTIONS
}

\author{
Romuald Bedzinski, Krzysztof Scigala
}

Division of Biomedical Engineering and Experimental Mechanics, Wroclaw University of Technology

romuald.bedzinski@pwr.wroc.pl

\section{Abstract}

The paper presents main aspects of modern orthopaedic implants design and operation. Influence of implant shape and especially stiffness characteristics and stress distribution on the surface of implant, which is in direct contact with bone, are presented. As the second factor influence of implant shape on the bone remodelling processes in the macro and micro scale was analyzed. Main distribution of general bone density as well as distribution of cancellous bone trabecules in the presence of implant is analyzed. Finally, new type of surface layer (including technology of layer manufacturing) was developed.

Keywords: bone - implant interactions; implant surface; remodelling; trabecular structure; endoprosthesis

\section{Introduction}

In contemporary implantology the long existing problem of implant fast degradation and its progressive dysfunction is given careful consideration $^{2}$. In majority of clinical cases, the reason for re-operation is the lack of proper cooperation between patient's bone tissue and an implant ${ }^{3}$. Problem of implant aseptic loosening in long postoperative time period is result of influence of various factors: mechanical, electrical, chemical and biological ones. Evaluation of implant shape, as well as criterions of implant design should be developed in the way allowing manipulating of implant shape with respect to implant - bone interactions.

In the process of implant design anatomical limitations should be taken into consideration. General shape of implant should fit to the surrounding tissue environment. On the other hand shape of the implant is strongly connected with stiffness characteristics of implant and that aspect should be also taken into consideration during design process ${ }^{4}$.
With other words, two different indications, which actually in most cases are opposite, should have great influence on the implant design process and final shape of the implantminimization of tissue distraction and modeling during implantation and minimization of difference between stiffness characteristics of implant and surrounding tissue.

From the point of view of implant - tissue connections, which develops in the postoperative time period, it should be mentioned so most essential issue is proper stress and strain distribution on the surface of implant, which is in direct contact with bone tissue. To provide proper implant osteointegration, some level of bone tissue loading is necessary to generate mechanical stimulus for bone cells activation. On the other hand bone loading level should be in the proper range to avoid immediate destruction of new implant - bone connection. Taking above into consideration it should be assumed that shear strain distribution is one of the most essential factors of implant shaping. 
Resuming, general implant shape should be design on the basis of two main mechanical factors: stiffness characteristics and shear stress distribution on the external surface, which is in contact with surrounding tissue.

In modern biomechanics it is considered, so mostly mechanical interaction between implant and bone leads to biological processes of bone functional adaptation $6,7,8,10,11$. Even, when all mechanical factors are in proper range, and the shape of implant is developed with respect to them, some negative adaptation processes can still exist (stress shielding, bone lysis, bone - implant integration at only part of contact surface ${ }^{4}$. Because of that, analysis of remodelling of tissues around implant should be carried out in every case, and additional implant shaping should be the next step of implant design ${ }^{5}$. It should be mentioned that it is necessary to investigate results of bone adaptation in macro as well as in micro level. In macro level main criterion of implant evaluation is difference of bone density distribution in physiological loading conditions (intact bone) and after implantation. In micro level main issue are proper trabecular structure (allowing load transfer with minimal mass) and the proper number of bone trabecules, which has direct contact with implant surface (ingrowth ratio).

Finally, it should be assumed that in the process of implant induced hypertrophy the surface layer, which is in direct contact with bone cells, plays key role ${ }^{9,13}$. Influence of material used for an implant cannot be underestimated in the process of implant evaluation as well as in process of implant design. Due to the structural role of bones, titanium alloys are the materials most often used. However application of even most modern titanium alloys also leads to problems with implants stiffness and non-compatibility with mechani- cal properties of surrounding tissues. Because of that development of new surface layers, which guarantee proper porosity, roughness and presence of elements "friendly" for osteointegration is the last, but not the least step in the implant design.

The main aim of this paper is to investigate main factors connected with bone - implant interactions:

- stiffness characteristics,

- shear stress distribution on the surface on the implant,

- changes in the density distribution of bone surrounding implant,

- development of trabecular structure on the surface of implant,

- surface layer of the implant.

\section{Material and method}

All investigations were carried out with focus on the stem of hip joint endoprostheses, as the most used orthopaedic implant.

In first step of investigations three-dimensional model of femur bone with stem was prepared, to investigate stiffness characteristics. Geometrical model of bone was prepared based on CT scans of Sawbone ${ }^{\circledR}$ intact femur bone model. Geometrical model of stem was prepared based on direct dimensions measurements. Virtual implantation (positioning of implant model in the model of femur) was carried out with evaluation of clinicians.

For discretisation of geometrical models solid, tetra-type elements, with 10-nodes and three degree of freedom at each node were used. Final FE meshes are presented at Figure 1. 


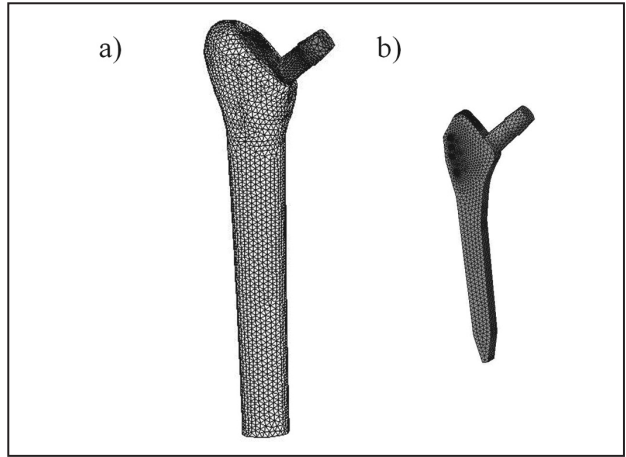

Figure 1. FE model of femur

with implanted stem (a), and stem (b)

Material of implant was assumed as linear elastic material.

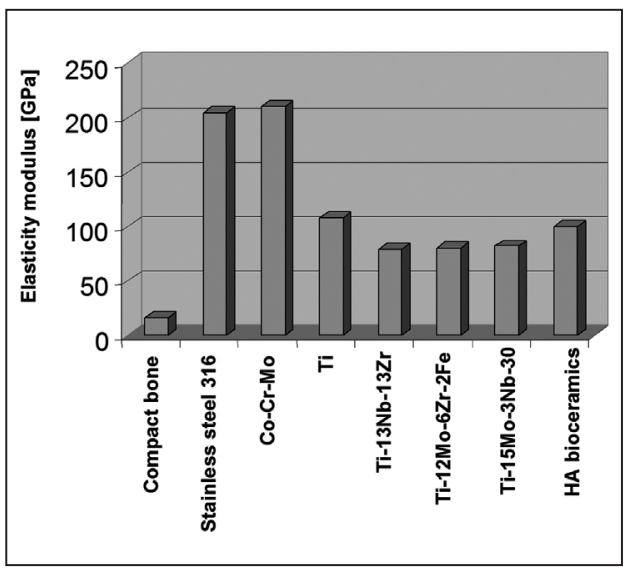

Figure 2. Comparison of mechanical properties of tissues and common implant materials
It can be easily assumed that any of the proposed for implant material is not in the range of mechanical properties of bone. However, for further comparative analysis there were chosen alloys: Ti-12Mo-6Zr-2Fe, Ti-12Al-6V, CoCr-Mo. Mechanical properties of those materials are given in Figure 2. Compact bone was assumed as elastic, orthotropic material, and cancellous bone as elasto-plastic, orthotropic material. Mechanical properties of both bone tissues are given in Table 1 and Table 2.

Two different analyses were carried out, firstly analysis of intact stem stiffness characteristics, secondly analysis of stiffness characteristic of bone - implant complex. In both cases models were loaded by bending in coronal plane, which was assumed as most essential type of loading for those types of analyses.

The same FE models were used in second step of project - analysis of shear stress on the external surface of implant. In that case the same discrete models and the same material models were used. Model of loading was in that case the Pawels model of single leg standing ${ }^{12}$.

The third step of the analysis was simulation of bone remodelling around stem of hip joint endoprosthesis. First analysis was carried out in macro scale using Carter model of bone remodelling?.

\begin{tabular}{|c|c|c|c|c|c|c|c|c|c|}
\hline \multirow[t]{2}{*}{ Type of tissue } & \multicolumn{3}{|c|}{$\begin{array}{c}\text { Elasticity modulus } \\
\text { E [GPa] }\end{array}$} & \multicolumn{3}{|c|}{ Poisson ratio $v$} & \multicolumn{3}{|c|}{$\begin{array}{c}\text { Kirchoff modulus } \\
G[\mathrm{GPa}]\end{array}$} \\
\hline & $\mathrm{X}$ & $Y$ & $\mathrm{Z}$ & $X Y$ & $\mathrm{YZ}$ & $X Z$ & $X Y$ & $Y Z$ & $\mathrm{XZ}$ \\
\hline Compact bone & 11.5 & 11.5 & 17.0 & 0.5 & 0.31 & 0.31 & 3.6 & 3.6 & 3.3 \\
\hline Cancellous bone & 0.318 & 0.318 & 0.965 & 0.38 & 0.104 & 0.104 & 0.15 & 0.15 & 0.1 \\
\hline
\end{tabular}

Table 1. Elastic properties of bone tissues

\begin{tabular}{|lccccccccc|}
\hline Type of tissue & \multicolumn{1}{c}{$\begin{array}{c}\text { Yield point for } \\
\text { tension } \\
\text { [MPa] }\end{array}$} & \multicolumn{3}{c}{$\begin{array}{c}\text { Yield point for } \\
\text { compression } \\
\text { [MPa] }\end{array}$} & \multicolumn{3}{c|}{$\begin{array}{c}\text { Yield point for shear } \\
\text { [MPa] }\end{array}$} \\
\cline { 2 - 10 } & $\mathrm{X}$ & $\mathrm{Y}$ & $\mathrm{Z}$ & $\mathrm{XY}$ & $\mathrm{YZ}$ & $\mathrm{XZ}$ & $\mathrm{XY}$ & $\mathrm{YZ}$ & $\mathrm{XZ}$ \\
Cancellous bone & 3.2 & 3.2 & 7.2 & 2.7 & 2.7 & 43.2 & 4.62 & 4.62 & 4.62 \\
\hline
\end{tabular}

Table 2. Yield properties of cancellous bone 
Biomechanica Hungarica I. évfolyam, 1. szám

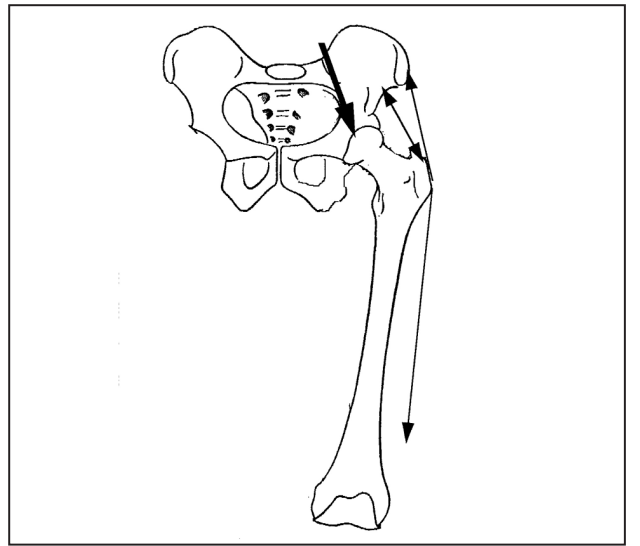

Figure 3. The Pawels model of hip joint loaded during one leg standing

In that case two-dimensional models of intact femur and femur with implant (both with side-plate proposed by Carter) were prepared $^{7,11}$. Geometrical model of femur was created based ont he previously used three dimensional model and the stem was directly measured. Side plates were copies of original bone models. For discretisation of models two-dimensional quadratic shell elements whit 8 nodes and three degree of freedom at each node were used. However, in further analysis degree of freedom perpendicular to plane of main model was blocked. For connection between main model and side plate there were used beam elements with 2 nodes and two degree of freedom (both in the plane of the main model).

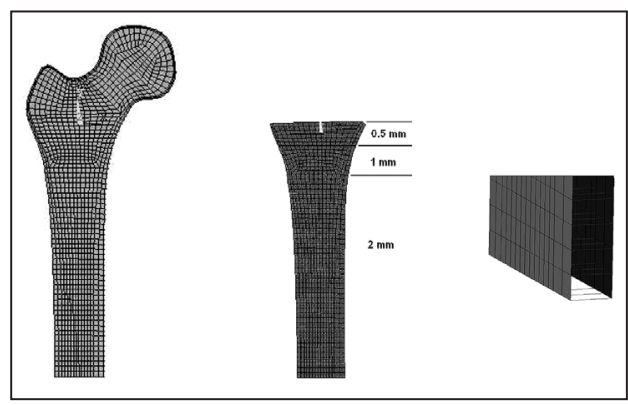

Figure 4. FE model used for remodelling simulation in macro scale
Material of implant, as well as materials of both bone tissues were assumed in that case as linear, elastic and isotropic materials (Table 3).

\begin{tabular}{lcc}
\hline \multicolumn{1}{c}{ Type of material } & $\begin{array}{c}\text { Elasticity modulus E } \\
{[\mathrm{GPa}]}\end{array}$ & $\begin{array}{c}\text { Poisson ratio } \\
\end{array}$ \\
\hline Implant & 105 & $v$ \\
Compact bone & 18,6 & 0,3 \\
Cancellous bone & 0,465 & 0,3 \\
\hline
\end{tabular}

Table 3. Mechanical properties in FE model used for remodelling simulation in macro scale

For loading model proposed by Beaupère to mimic gait loading was used ${ }^{7,14}$.

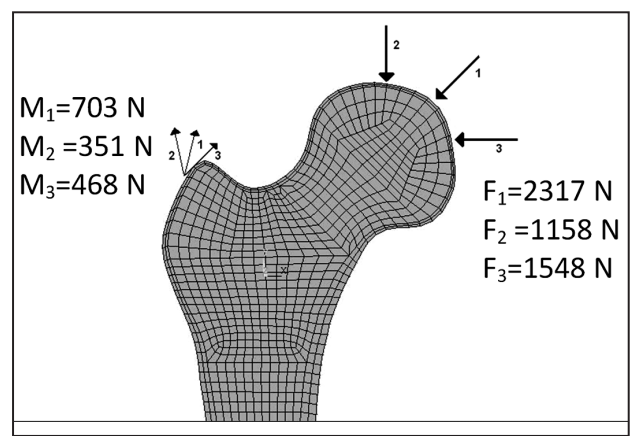

Figure 5. Beaupère model of hip joint loading for standing phase of gait cycle

Three-linear model of Carter, which was used for simulation of remodelling, was improved by addition of model of tissue destruction in case of high overloading which is one of the most essential symptoms of implant loosening.

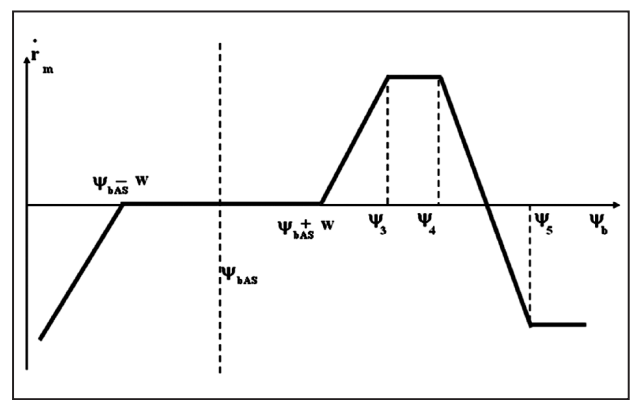

Figure 6. Model of bone remodelling used for simulations in macro scale 
For every element of FE model, strain energy density was calculated based on the results of FE calculations. Next, effective stress values were calculated. Mechanical stimulus for remodelling at each element was calculated basing on formula:

$$
\psi=\left[\sum_{i=1}^{N} n_{i} \sigma_{e f i}^{m}\right]^{1 / m}
$$

where:

$\mathrm{N}$ - number of loading cases

$\mathrm{n}$ - number of loading cycles

$\sigma_{\text {efi }}-$ effective stress for load case i

$\mathrm{m}$ - empirical constant

Using above model of remodelling (Figure 6) values of bone apposition/reposition ratio were found. Using information about bone surface/trabecular volume ratio estimation of values of change of bone density was carried out. New values of bone density and bone mechanical properties were final calculations in single iteration of simulation procedure. For simulation there were used further values of constants:

- average daily mechanical stimulus $50 \mathrm{MPa}$ /day

- initial value of bone density $-0.5 \mathrm{~g} / \mathrm{cm}^{3}$

- half of "lazy" zone - $12.5 \mathrm{MPa} /$ day

- slope of line in absorption and resorption zone -0.02

- number of load cycles $-\mathrm{n}_{1}=6000, \mathrm{n}_{2}=$ $\mathrm{n}_{3}=2000$

For simulations of bone remodelling in micro scale FE models of microstructure of bone trabecular structure were prepared. In initial stage isotropic homogenous structure of trabecules, developed using circular shapes with the same diameter was proposed ${ }^{14}$. For discretisation two-dimensional quadratic elements, with 4 nodes and two degrees of freedom were used. In that case in all FE models element size was pixel size in final result.

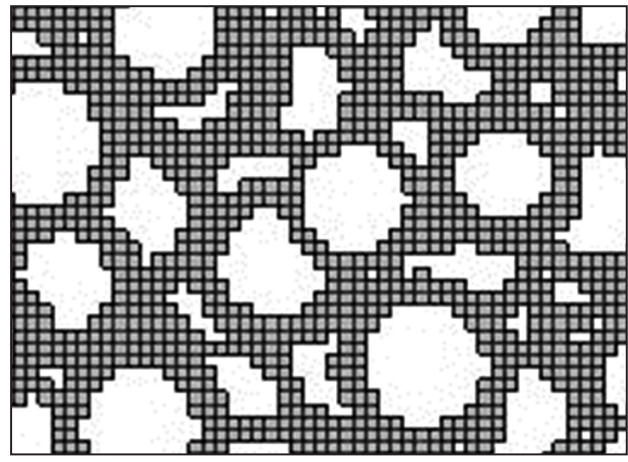

Figure 7. FE model of bone trabecular structure

Because of that, in each case, time of calculations is extremely long, so only models of bone tissue specimen were used.

The properties of materials used in micro scale FE models are shown in Table 4.

\begin{tabular}{lcc}
\hline \multicolumn{1}{c}{ Type of material } & $\begin{array}{c}\text { Elasticity modulus E } \\
{[\mathrm{GPa}]}\end{array}$ & $\begin{array}{c}\text { Poisson ratio } \\
\end{array}$ \\
\hline Implant & 105 & 0,3 \\
Trabecular bone material & 20 & 0,3 \\
\hline
\end{tabular}

Table 4. Mechanical properties in FE model used for remodelling simulation in micro scale

Loading of model was estimated based on nodal displacement in macro model. For proposed bone specimen proper lines were located in macro FE model of bone with implant. Nodes located along those lines were examined for nodal displacements, which are result of Beaupère model loading. The same values of nodal displacements were applied to the perimeter of bone specimen model.

To estimate trabecular remodelling stimulus stress distribution on the trabecular surface was calculated (Figure 8).

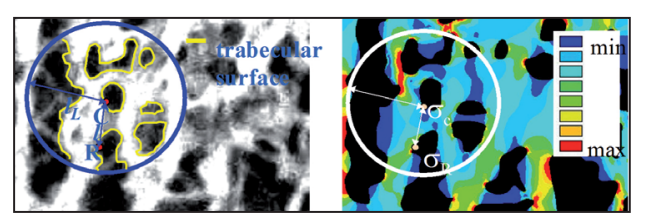

Figure 8. Evaluation of local stress nonuniformity $(\Gamma)$ 
For estimation of surface remodelling stimulus. The formulas here below was used ${ }^{1,14,15}$ :

$$
\begin{gathered}
\Gamma=\ln \left(\frac{\sigma_{c}}{\sigma_{d}}\right) \\
\sigma_{d}=\int_{S} w(L) \sigma_{R} d S / \int_{S} w(L) d S \\
w(L)= \begin{cases}1-\frac{L}{L_{L}} & \left(0<L<L_{L}\right) \\
0 & \left(L_{L} \leq L\right)\end{cases}
\end{gathered}
$$

where:

$\Gamma$ - local stress nonuniformity (remodelling stimulus)

$\sigma_{\mathrm{c}}-$ von Mises stress at point $\mathrm{C}$

$\sigma_{\mathrm{R}}$ - von Mises stress at point $\mathrm{R}$ of surface $\mathrm{S}$ in the distance $\mathrm{L}$ from point $\mathrm{C}$

$\mathrm{L}_{\mathrm{L}}$ - radius of circular area where cells can sense a mechanical stimulus

Based on the values of local stress nonuniformity, change of trabecular mass was calculated. In the FE model change of mass was realized by addition of new elements on the trabecular surface or by removing existing ones.

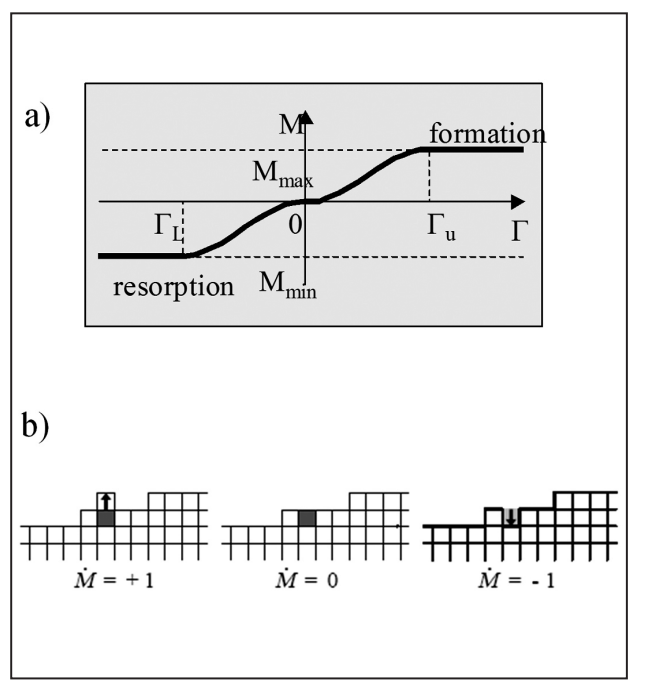

Figure 9. Trabecular structure mass change (a) and $\mathrm{FE}$ realization (b)
Simulation was realized in several iterations of procedure based on above algorithm.

For investigations of new type implant surface layer new method of fabrication of the thin films obtained by the sol-gel method for medical applications has been developed. Materials are prepared from hydrolyzed alkoxides of silicon and titanium (or their mixtures). First coating was based on precursor TIPO - titanium (IV) isopropoxide, second on TBOT - titanium (IV) n-butoxide and third on VTES - vinyltrietoxysilane. The first and second sample where therefore sol-gel coatings based on titanium and the third one was based on the silicon.

All samples were then coated with different sol-gel coatings using spin-coating, dip-coating or simple painting.

\section{Results}

Results of first stage of investigations can be divided into two parts. First investigations of bending stiffness characteristics for exemplary stem of hip joint endoprosthesis shows influence of material used for stem manufacturing. Three different alloys were examined. Highest value of maximal bending stiffness (in the region of stem neck) was obtained for model of stem manufactured using Co-Cr-Mo alloy. Value of bending stiffness in the same region for stem manufactured using Ti-12Al-6V alloy is almost $45 \%$ lower.

Value of bending stiffness for the stem manufactured using $\mathrm{Ti}-12 \mathrm{Mo}-6 \mathrm{Zr}-2 \mathrm{Fe}$ alloy is $61 \%$ lower than for first stem and $30 \%$ lower than for second stem. It should be mentioned that using $\mathrm{Ti}-12 \mathrm{Mo}-6 \mathrm{Zr}-2 \mathrm{Fe}$ alloy is still rarely used in modern clinical solution. However, even application of that alloy changes stiffness in the range non-satisfactory from the point of view of implant - bone interactions. 


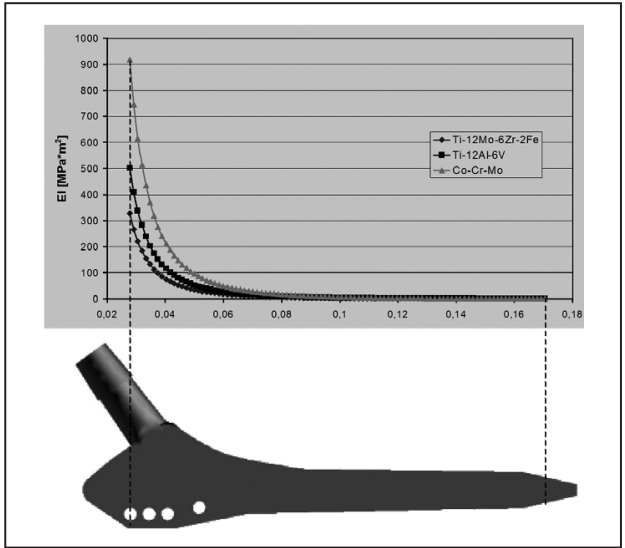

Figure 10. Stiffness characteristics of stem of hip joint endoprosthesis manufactured using various alloys

Similar assumptions come from analysis of results of second part of first stage investigations.

Bending stiffness characteristics for implant bone complex shows that maximal value of bending stiffness changes when various alloys for stem manufacturing are used. However, shape of characteristic doesn't change, and for every type of alloy values of bending stiffness are significantly higher than for intact bone ${ }^{2}$

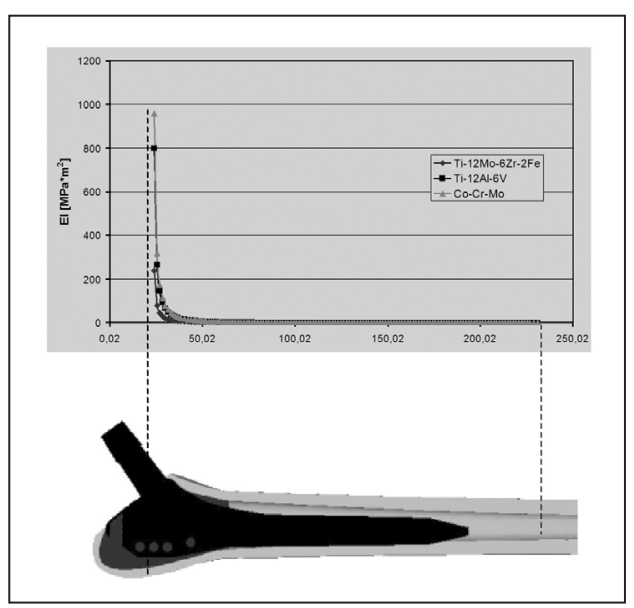

Figure 11. Stiffness characteristics of stem - bone complex
Results clearly show that proper material for stem for implant has significant influence on implant fitting to surrounding tissue environment. On the other hand, results show also that proper implant shaping is necessary to obtain real improvement of implant design. Especially nowadays, when modern manufacturing technologies offer techniques allowing implant shaping in the range, which never existed, new designs of implants, whit complete respect to bone - implant interactions in macro scale are necessary.

Results of second stage of investigation show that evaluated stem should be redesigned also from the point of view of shear stress distribution on the external implant surface. In all surface shear strains have values which are safe for development of new tissue - implant surface connections. Only in the upper, medial part of stem surface, some strain concentrations are visible. In that region newly developed connections of bone tissue to implant surface have proper stimulus to growth, but development is disordered by damage of bone tissue coming from shear loading. Considering all components of shear strains along $\mathrm{x}, \mathrm{y}$ and $\mathrm{z}$ axis it can be observed that for proposed load model tissue overloading is complex and connected with distribution of shear strain along all the three axes.

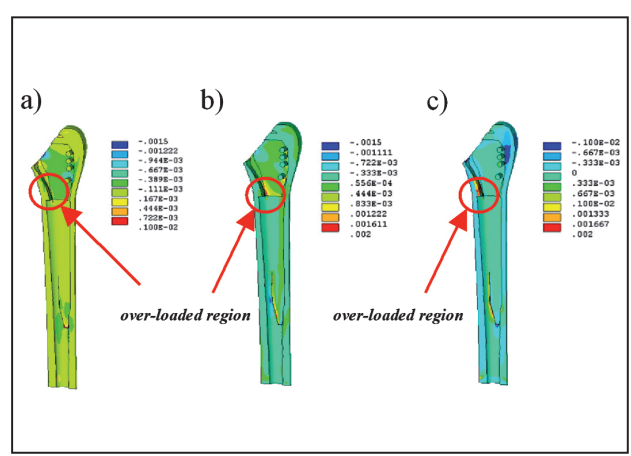

Figure 12. Distribution of shear strains on the external surface of implant (a) along $x$ axis, (b) along $\mathrm{y}$ axis, (c) along $\mathrm{z}$ axis 
Biomechanica Hungarica I. évfolyam, 1. szám

Results of third stage of implant analysis show significant differences in bone density distribution for intact bone and bone with implanted stem of hip joint endoprosthesis.

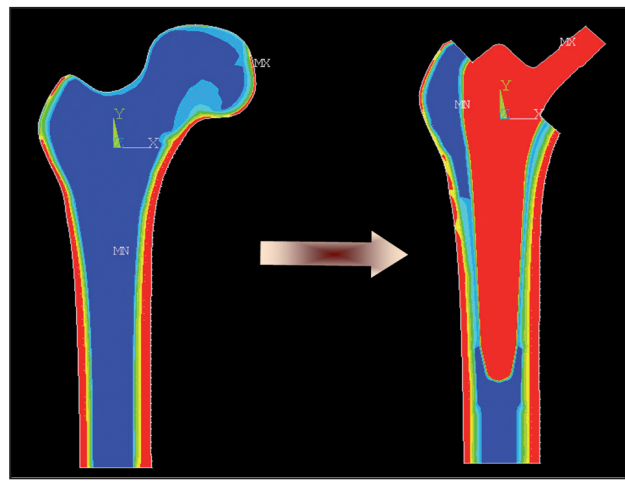

Figure 13. Distribution of bone density in the model of intact bone and in the model of bone with implant (red - maximal value of density, blue - minimal value of density)

In the case of intact bone we can observe welldeveloped layer of compact bone (red color) in the upper and lower part of analyzed region.

It can be also observed some region of bone tissue in the lower part of femur neck and head with significantly high density values, which is direct response of bone on the loading. In the model of femur with stem of hip joint endoprosthesis we can observe negative bone remodelling in the lower part of stem (bone resorption). Compact bone layer is in this region significantly thinner. In the medial region of stem we can observe well-developed intermediate layer between stem external surface and compact bone layer. We can observe that kind of layer on the medial as well as on the lateral side of stem. In the upper part of stem on the lateral side bone tissue is also well developed, so for first look connection of implant and bone seems to be proper. However, looking closely, we can see thin sub-layer in the middle of the distance between implant surface and compact bone. Density value for this sub-layer is significantly lower than in the rest part of region. The same effect observed using $\mathrm{x}$-ray examination, in clinical practice is assumed as symptom of implant loosening.

Simulation of trabecular remodelling in the same region shows structure properly developed for load transfer. Structure is highly directed, mostly vertically oriented trabecules can be observed. Some inter-trabecular horizontal connection are also visible, but thinner than vertical trabecules.

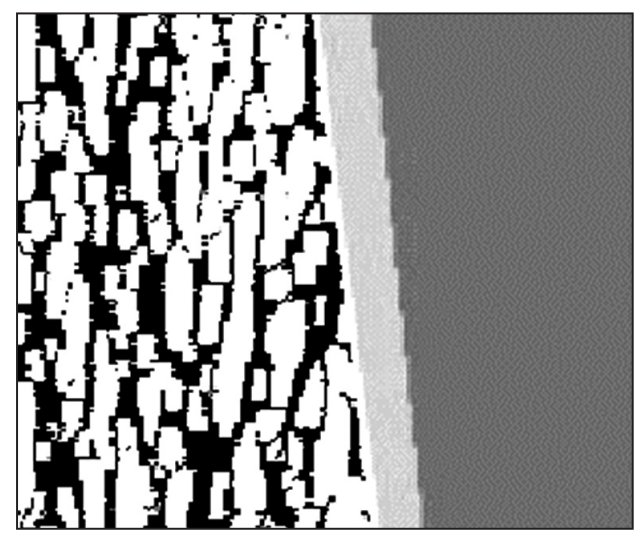

Figure 14. Distribution of cancellous bone trabecules in the region of implant surface

Additionally, only small number of trabecules is directly connected to the surface of implant. The next indication is that the implant in that region should be redesigned, by changing external shape as well as by preparing proper surface layer.

Examination of new sol-gel layers prepared for the surface of implant shows that no cracks or delamination of layer connected with the layer manufacturing exist. That kind of examination was conducted using SEM and ATM microscopy. Evaluation of surface roughness shows proper level of surface unevenness. 


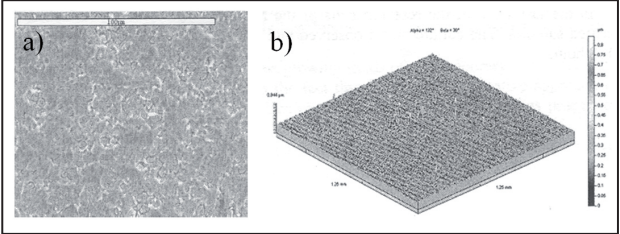

Figure 15. SEM microscopy image of $\mathrm{TiO}_{2}$ (a), roughness graph of $\mathrm{TiO}_{2}$ coating (b)

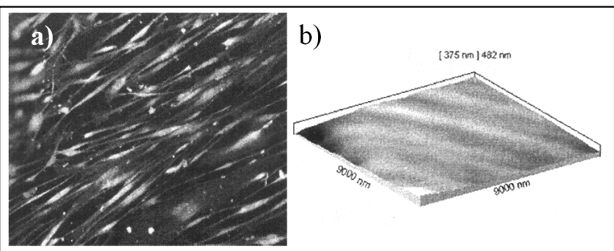

Figure 16. AFM micrograph of $\mathrm{TiO}_{2}$ coating (a) cells culture-fluorescence (b)

First results of bone cells seeding on sol - gel surfaces also show that application of that kind of surface layers to covering implants can lead to proper development of bone ingrowth process.

\section{Conclusions}

Presented results prove that proper bone implant interactions can be secured only after consideration of factors influencing on bone ingrowth process in macro and micro scale. Four main factors: stiffness characteristics, shear stress distribution on the external implant surface, changes in density distribution after implantation, trabecular structure development and remodelling and surface layer plays essential role in implant fitting to surrounding tissues environment. It was also shown that existing implants are significantly far from perfect stiffness characteristics. Specially, most often problems of implant - bone interactions occurs in the upper lateral part of hip joint endoprosthesis because of shear stress distribution and in some level negative bone remodelling. There is some probability that development of new surface layer as well as implant re-shaping in that region can lead to the solution of the problem.

\section{REFERENCES}

1. Adachi $T$, et al. Functional adaptation of cancellous bone in human proximal femur predicted by trabecular surface remodelling simulation toward uniform stress state. Journal of Biomechanics 2002;35:1541-51.

2. Bedzinski R. Biomechanical Engineering: Selected Topics. Oficyna Wydawnicza Politechniki Wrocławskiej 1997. (in Polish)

3. Bedzinski R. Bone - implant interaction. Engineering of Biomaterials 2002;131-6.

4. Bedzinski R, Bernakiewicz $M$, Scigala $K$. Biomechanical aspects of artificial joint implantation in a lower limb. Journal of Theortical and Applied Mechanics 1999;37:455-81.

5. Bedzinski R, Scigala K. FEM analysis of strain distribution in tibia bone and relationship between strains and adaptation of bone tissue.
Proceedings of the $2^{\text {nd }}$ European Conference on Computational mechanics; 2001; Krakow, Poland.

6. Bombelli R. Structure and function of normal and abnormal hips. Berlin: 1993.

7. Carter D, Beaupère $G$. Skeletal function and form. Cambridge: Cambridge University; 2001.

8. Cowin SC, Hart RT, Balser JR, Kohn DH. Functional Adaptation in Long Bones: Establishing in vivo Values for Surface remodelling Rate Coefficients. Journal of Biomechanics 1985; 18:665-84.

9. Friedman, R. J., et al.: Influence of biomaterial surface texture on bone ingrowth in the rabbit femur. Journal of Orthopedics Research 1991; 3:455-64. 
Biomechanica Hungarica I. évfolyam, 1. szám

10. Frost, H.: A determinant of bone architecture. The minimum effective strain. Clinical Orthopedic 1987; 113-49.

11. Huiskes, R., Weinans, H. J.: Adaptive boneremodelling theory applied to prosthetic-design analysis. Journal of Biomechanics 1987; 20:1135-49.

12. Maquet, P. G. J.: Biomechanics of the hip. Berlin: 1985.

13. Peltola, T.: Improved in vitro reactivity and in vivo tissue response with nanoporous titanium surface. Conference Materials of the $1^{\text {st }}$ Polish-
Finnish Symposium on Functional sol-Gel Materials; 2005; Wroclaw, Poland.

14. Tsubota, K., Adachi, T., Tomita, Y.: Functional adaptation of cancellous bone in human proximal femur predicted by trabecular surface remodelling simulation toward uniform stress state. Journal of Biomechanics 2002; 35:1541-51.

15. Tsubota, K., Adachi, T.: Spatial and temporal regulation of cancellous bone structure: characterization of a rate equation of trabecular surface remodelling, Medical Engineering \& Physics 2005;27:305-11.

This work was supported by Polish Ministry of Science and Higher Education. Grant No. N507 009 31/0275

Romuald Bedzinski

Division of Biomedical Engineering and Experimental Mechanics,

Wroclaw University of Technology

Lukasiewicza 7/9 50-371 Wroclaw, Poland

tel.: $(+48) 71320-27-13$

\section{A Debreceni Egyetem OEC Ortopédiai Klinikája akkreditált, kötelezốen választható továbbképzési kurzust hirdet „A prototípuskészítés sebészi alkalmazási lehetôségei” címmel.}

Helyszín: Debreceni Egyetem, Biomechanikai Laboratórium · 4028 Debrecen, Ótemetô u. 2-4

Idốpont: 2008. október 1.

A kurzus programja:

9:00-12:00 A Rapid Prototyping technológia és az orvoslás (Elöadó: dr. Csernátony Zoltán egy. docens)

13:00-16:00 3D szerkesztés és nyomtatás orvosi képalkotó eljárások alapján

(Elöadó: dr. Csernátony Zoltán egy. docens és Manó Sándor tudományos segédmunkatárs)

OFTEX-kódszám: deoec/2008-07/00293

A kurzus teljesítéséért 12 továbbképzési kredit, illetve 0,21 PhD kredit szerezhetô.

Jelentkezni a http://aok.unideb.hu/oktatas/szak_es_tovabb/kot_foly/jellapkottk2007.doc címrôl letölthető jelentkezési lap kitöltésével és a Debreceni Egyetem Orvos- és Egészségtudományi Centrum Szak- és Továbbképzési

Központhoz való eljuttatásával lehet.

Cím: 4012 Debrecen, Nagyerdei krt. 94.

Fax: (+36) 52 424-923

További információk a kurzusról: DEOEC Ortopédiai Klinika ·(+36) 52 415-494·csz@med.unideb.hu 